\title{
Plant diversity patterns and conservation status of eastern Himalayan forests in Arunachal Pradesh, Northeast India
}

\author{
P. Saikia', J. Deka ${ }^{2}$, S. Bharali ${ }^{3}$, Amit Kumar ${ }^{1}$, O. P. Tripathi', L. B. Singha ${ }^{4}$, S. Dayanandan ${ }^{5}$ and M. L. Khan ${ }^{6 *}$ (D)
}

\begin{abstract}
Background: The State of Arunachal Pradesh is part of the Himalaya biodiversity hotspots distributed over an area with the largest elevation gradients in the world, ranging from lowland tropical forests to alpine vegetation.

Methods: The vegetation was surveyed along an elevation gradient ranging from 87 to $4161 \mathrm{~m}$ in 354 belt transects (500 m $\times 10 \mathrm{~m}$ in size) and analyzed using various ecological indices.

Results: A total of 482 (458 identified, 24 unidentified) plants were recorded in the present study, of which 153 are nonwoody herbs and grasses (145 identified) belonging to 55 families, and 329 are woody trees and shrubs (313 identified) belonging to 74 families. The 458 identified species belong to 117 families and 251 genera, of which $94.10 \%$ are phenerogams (Angiosperms: 421 species [spp.] and Gymnosperms: 10 spp.) and 5.90\% cryptogams (Pteridophytes: 27 spp.). The family Fabaceae contributed the greatest species diversity with a total of 27 plant species (Papilionaceae: 10 spp., Mimosaceae: 9 spp. and Caesalpinaceae: 8 spp.) followed by Poaceae (21 spp.), Ericaceae (20 spp.), Asteraceae (18 spp.), Lauraceae (17 spp.), Euphorbiaceae (16 spp.), Urticaceae (15 spp.) and 49 monotypic families. The most dominant trees were Castanopsis indica (24 individuals per ha), followed by Quercus semicarpifolia (12 individuals per ha) and Pinus roxburghii (12 individuals per ha) and some bamboos (Dendrocalamus strictus: 69 individuals per ha; Bambusa pallida: 16 individuals per ha). The studied forest stands were rich in various bamboos; a total of 14 different bamboos were recorded in the present study including Dendrocalamus strictus, Bambusa tulda, B. pallida etc. Common IUCN red-listed species were Aquilaria malaccensis, Begonia tessaricarpa, Gledetsia assamica, Gymnocladus assamicus, Livistona jenkinsiana, Rhododendron meddenii, Rhododendron thomsonii collected from the Dirrang, Tawang, Yamcha, Itanagar, Along and Mebo areas of Arunachal Pradesh.

Conclusion: The results confirm that the Eastern Himalayan forests are very rich in terms of species diversity which decreases with increasing elevation. Species richness and distribution patterns of plants are largely regulated by altitude and other environmental factors. Intensive monitoring and management is needed to protect this fragile ecosystem from the ever-increasing anthropogenic pressure and changing climatic conditions.
\end{abstract}

Keywords: Species richness, Endemic species, Forest ecosystems, Eastern Himalayan region

\section{Background}

The vegetation is a fundamental component of ecosystems that reflects the effects of the total environment (Billings 1952). Plants grow collectively in a specific ecosystem and have a mutual relationship among themselves as well as within the local environment (Mishra et al. 1997), which results in the formation of different vegetation types in

\footnotetext{
* Correspondence: khanml61@gmail.com

${ }^{6}$ Department of Botany, Dr. Harisingh Gour Central University, Sagar, Madhya Pradesh 470003, India

Full list of author information is available at the end of the article
}

different regions. Forests are important as they provide various ecosystem services such as species conservation, prevention of soil erosion and preservation of habitat for plants and animals (Li et al. 2003; Armenteras et al. 2009). Tree species diversity is the determinant of total forest biodiversity as trees provide resources as well as habitats for almost all other forest species (Haung et al. 2003). In forest ecosystems, tree species diversity varies greatly from place to place mainly due to variation in biogeography, habitat and disturbance (Whitmore 1998). Environmental variability in terms of climatic factors, social resources, 
grazing by herbivores and human interference are the critical factors which regulate the spatial and temporal patterns of the vegetation of an ecosystem (Chapin et al. 1993). However, the composition of vegetation is fluctuating and continuous modification takes place depending upon the temperature, moisture, sunlight and available nutrients (Heady 1958). Tropical forests constitute the most diverse plant communities on earth. However, these forests are disappearing at the alarming rate of 13.5 million hectares per year globally (Kobayashi 2004). It is estimated that around 7500 species of organisms are becoming extinct every year (Chatterjee 1995) and many of them disappear even before they are known to the scientific world (Myers et al. 2000; Pimm and Raven 2000). Ecological and environmental problems such as soil degradation, soil erosion and overexploitation of natural resources are just some of the negative effects resulting from the destruction of natural ecosystems (Hundera et al. 2007). Furthermore, floristic diversity along with the respective habitat is also rapidly declining. The loss of any such forest resource will have great implications for the environment, the biological diversity as well as the socio-economic setup of local communities.

The state of Arunachal Pradesh located in the eastern Himalayan region is part of the Himalaya biodiversity hotspots. It is the largest mountainous state of India and recognized as a globally important eco-region (out of 200). It comprises over 5000 species of plants, which are distributed along one of the largest elevation gradients in the world, ranging from lowland tropical forests to alpine vegetation in the Himalayan Mountains. According to FSI report (2015), forest cover in Arunachal Pradesh is $67,248 \mathrm{~km}^{2}$; it is ranked as second in terms of forested areas after Madhya Pradesh $\left(77,462 \mathrm{~km}^{2}\right)$. On the other hand, it ranks $4^{\text {th }}$ in terms of percentage of forest cover (80.30\%). In the Himalayan ranges of Arunachal Pradesh, the vegetation ranges from tropical mixed and broadleaf evergreen forest to alpine meadow and scrub, across large elevation gradients. Knowledge of ecological processes and biotic interference helps in understanding the stability of well-established plant communities as ecological, biotic and anthropogenic disturbances are prevalent all over the Himalaya (Singh and Singh 1991). Determining the composition, structure and function of forest ecosystems is of great ecological value not only for the understanding of energy and element flows within the ecosystem, but will also serve as an indicator of ecological impacts (Ramachandra et al. 2013). It is imperative to have an assessment of the current status of the natural stands of plant resources, their geographic distribution and population structure so that it will be possible to evaluate the various levels of threats and to develop working plans for the management and conservation of these forest resources. Therefore, the present research has attempted to study the plant diversity pattern in the Eastern Himalayan forests of Arunachal Pradesh, Northeast India over an area of 177 ha spread along different altitudinal gradients.

\section{Methods \\ Study sites}

Arunachal Pradesh is the largest state in the northeastern region of India and situated between $26^{\circ} 28^{\prime} \mathrm{N}$ to $29^{\circ} 30^{\prime} \mathrm{N}$ latitude and $91^{\circ} 30^{\prime} \mathrm{E}$ to $97^{\circ} 30^{\prime} \mathrm{E}$ longitude. The total geographical area is $83,743 \mathrm{~km}^{2}$, with a population density of 17 individuals per $\mathrm{km}^{2}$ (Census of India 2011). The state is predominantly hilly and mountainous. It is bordered by China to the north and northeast $(1080 \mathrm{~km})$, separated by the McMohanline, Bhutan $(160 \mathrm{~km})$ in the west, and Myanmar $(440 \mathrm{~km})$ in the east, and in the south by the Indian states of Assam and Nagaland. The state is divided into 16 districts (Fig. 1). The climate is exceptionally hot and humid at the lower altitudes and in the valleys, while it becomes exceedingly cold in the higher altitudes. The average mean minimum and maximum temperature ranges between $17.7{ }^{\circ} \mathrm{C}$ and $29.5{ }^{\circ} \mathrm{C}$ in the subtropical humid regions, and $2.4{ }^{\circ} \mathrm{C}$ and $21.4{ }^{\circ} \mathrm{C}$ in the cold humid regions. Generally, the winter months (December-February) are the coldest months. July and August are the warmest months with the average maximum temperature during this period being about $30{ }^{\circ} \mathrm{C}$. However, sometimes the temperature rises as high as $35{ }^{\circ} \mathrm{C}$ during summer in the plains and in the broad valleys. The mean annual rainfall ranges from 209 to $297 \mathrm{~cm}$. East Siang and the neighbouring areas of Lohit District experience the highest rainfall, whereas, in the West Kameng District the rainfall is the lowest. Almost all vegetation types are represented in the state of Arunachal, i.e. tropical, sub-tropical, temperate, and alpine. Bamboos grow along the foothills and grasslands cover the riparian tracts. The tropical and subtropical vegetation types are characterized by a great diversity.

\section{Grid generation and vegetation sampling}

The area of topographical sheets $(1: 50,000)$ as per Survey of India was divided into 16 grids with the help of GIS software. The entire state was covered by a total of 1920 grids, each grid occupying approximately $6.25 \mathrm{~km} \times$ $6.25 \mathrm{~km}$ area. Details of the grids in different districts of Arunachal Pradesh are presented in Table 1. The vegetation was studied using the belt transect method, and transects of $500 \mathrm{~m} \times 10 \mathrm{~m}$ were laid in each of the 349 selected grids of the 14 districts of Arunachal Pradesh. As a rule, one transect was to be positioned in each grid, but due to difficulties concerning the location identification in the field, five transects were wrongly positioned within the already sampled grids. The transects were further divided into five separate quadrats and the dimension of each quadrat was maintained as per decided standard (i.e., 


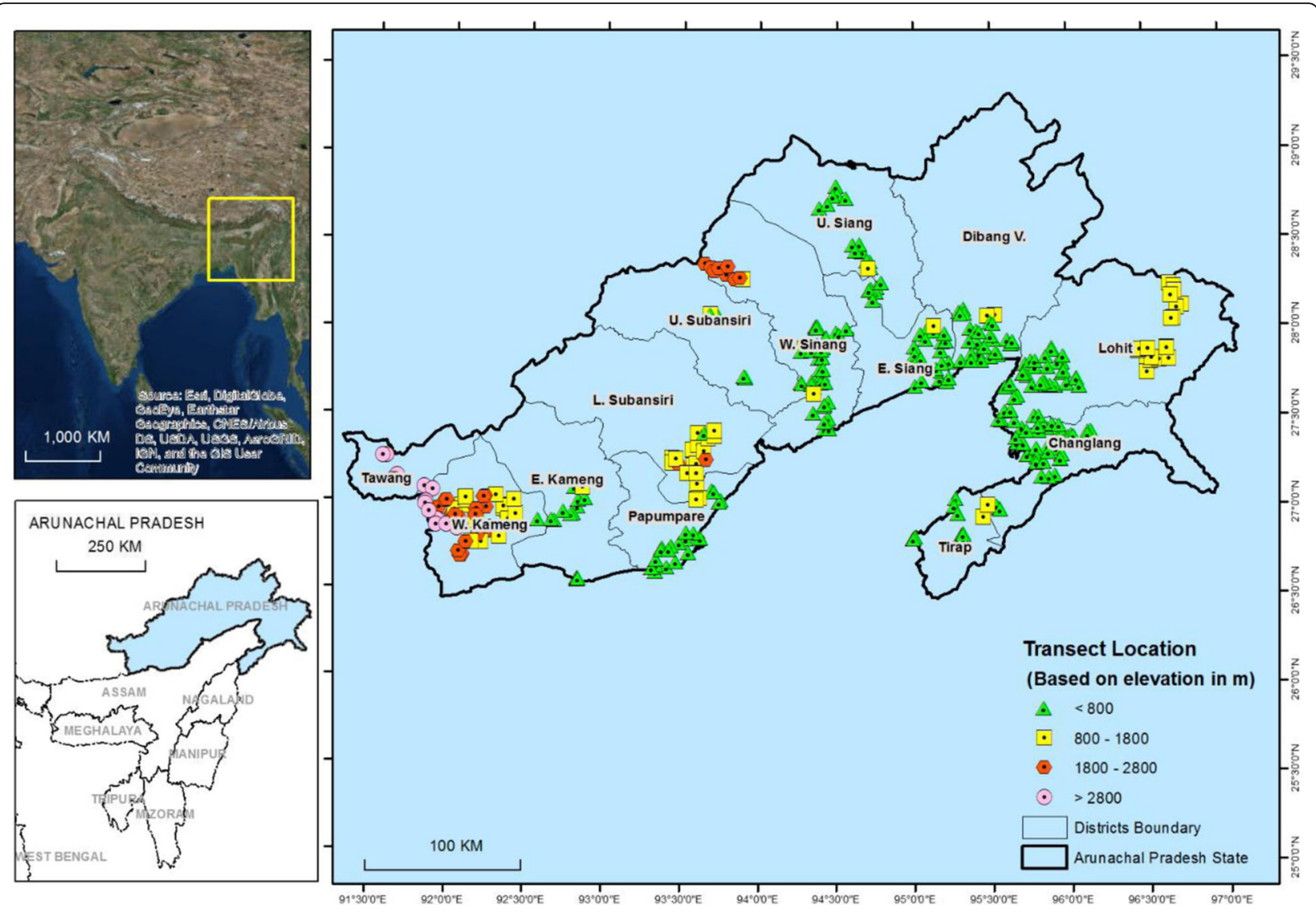

Fig. 1 Map of the study sites (State of Arunachal Pradesh, Northeast India) showing the locations of studied transects at different altitudinal gradients

Table 1 Details of grids per district and percentage covered in the present study

\begin{tabular}{lllll}
\hline Name of the Districts & Total No. of Grids & No. of grids sampled & No. of transect sampled & \% of grid coverage \\
\hline Anjaw & 134 & 21 & 21 & 15.67 \\
Changlang & 101 & 39 & 40 & 38.61 \\
Dibang Valley & 176 & - & - & - \\
East Kameng & 137 & 16 & 17 & 11.68 \\
East Siang & 89 & 18 & - & 20.22 \\
Kurung Kumey & 138 & - & 38 & - \\
Lohit & 110 & 36 & 35 & 32.73 \\
Lower Dibang valley & 142 & 35 & 21 & 24.65 \\
Lower Subansiri & 90 & 21 & 21 & 23.33 \\
Papumpare & 77 & 20 & 6 & 25.97 \\
Tawang & 61 & 6 & 10 & 9.84 \\
Tirap & 27 & 10 & 20 & 37.04 \\
Upper Siang & 181 & 20 & 7 & 11.05 \\
Upper Subansiri & 153 & 7 & 51 & 4.58 \\
West Kameng & 121 & 51 & 49 & 42.15 \\
West Siang & 183 & 49 & 354 & 26.78 \\
Total & 1920 & 349 & & 18.18 \\
\hline
\end{tabular}


$10 \mathrm{~m} \times 100 \mathrm{~m})$, although in some places the standard was adapted to cover the desired transect area due to geomorphological constraints such as escarpments in the field. The GBH and visual height of all plant species in the transects with $\geq 10 \mathrm{~cm}$ girth at breast height were recorded in standard data reporting sheets. Two quadrats measuring $1 \mathrm{~m} \times 1 \mathrm{~m}$ were laid out within each transect for enumeration of herbaceous species as well as seedlings of trees and shrubs. Herbarium specimen of each species were collected and sufficient numbers of field photographs were taken. Species were identified by consulting herbaria, existing literature and the respective vernacular names, which were further verified by the Botanical Survey of India, Itanagar, Arunachal Pradesh.

\section{Data analysis}

Quantitative analysis of the vegetation was done following Misra (1968). The Importance Value Index (IVI) was computed by summing up relative density, relative frequency, and relative dominance. The species richness was calculated by using the method 'Margalef's Index of Richness' (Dmg) (Magurran 1988).

$$
\operatorname{Dmg}=(S-1) / \ln N
$$

where $S$ is total number of species, $N$ is total number of individuals.

The Shannon-Wiener Diversity Index $(H$, Shannon and Wiener 1963) was calculated from the IVI values using the formula given by Magurran (1988)

$$
H=-\sum_{i=1}^{s} p_{i} \ln p_{i}
$$

where $p_{i}$ is the proportion of the IVI of $i^{\text {th }}$ species and the IVI of all the species $\left(n_{i} / N\right)$.

The Concentration of Dominance (CD) was assessed by Simpson's Index (Simpson 1949)

$$
\mathrm{CD}=\sum_{i=1}^{s}\left(P_{i}\right)^{2}
$$

where $p_{i}$ is the same as for the Shannon-Wiener information function.

The Evenness Index $(E)$ was calculated from the Shannon-Wiener Diversity Index using the formula.

$$
E=H^{\prime} / H_{\max }^{\prime}
$$

where $H^{\prime}$ is the Shannon-Wiener Diversity Index and $H^{\prime}{ }_{\text {max }}=\ln S$ (where $S$ is a total number of species).

The ratio of abundance to frequency was used to interpret the distribution pattern of the species (Whitford 1949). The ratio of abundance to frequency indicates regular distribution if below 0.025 , random distribution if between
0.025 and 0.05 , and contagious distribution if $>0.05$ (Curtis and Cottam 1956).

\section{Results}

The Eastern Himalayan forests in Arunachal Pradesh, Northeast India, are rich in terms of floristic composition. In the present study, a total of 482 (458 identified, 24 unidentified) plant species were recorded, of which 153 were non-woody herbs and grasses (145 identified) belonging to 55 families, and 329 were woody trees, and a variety of shrubs (313 identified) belonging to 74 families. The 458 identified species belong to 117 families and 251 genera, of which $94.10 \%$ phanerogams (Angiosperms: 421 spp. and Gymnosperms: 10 spp.) and 5.90\% cryptogams (Pteridophytes: 27 spp.). Out of the 421 angiosperms, 369 spp. were dicots and 52 spp. were monocots. The most diverse Dicot, Monocot, Gymnosperm and Pteridophytic families were Fabaceae (27 spp.), Poaceae (21 spp.), Pinaceae (6 spp.) and Pteridaceae (10 spp.) respectively. The maximum diversity of species was contributed by the family Fabaceae with a total of 27 plant species (Papilionaceae: 10 spp., Mimosaceae: 9 spp. and Caesalpinaceae: 8 spp.) followed by Poaceae (21 spp.), Ericaceae (20 spp.), Asteraceae (18 spp.), Lauraceae (17 spp.), Euphorbiaceae (16 spp.), Urticaceae (15 spp.), whereas 49 families were monotypic, represented by single species. In the case of woody plants, Ericaceae was the most dominant family with 20 different plant species, followed by Fabaceae with 19 species (Papilionaceae: 4 spp., Mimosaceae: 7 spp. and Caesalpinaceae: $8 \mathrm{spp}$.), whereas 23 families were monotypic represented by single species. Asteraceae was the most species-rich family (15 spp.) in the case of herbs and grasses, followed by Pteridaceae with 10 species (a Pteridophytic family), whereas 28 families were monotypic represented with single species.

The study shows that the majority of transects have a number of 200-400 individuals followed by transects with $<200$ individuals, whereas the majority of transects have a species diversity ranging from 20 to 30 species followed by transects with 10-20 species (Fig. 2 and Table 2). The species richness ranges from 0 to 64 with a mean of $22( \pm 0.65 \mathrm{SE})$ per transect, whereas the tree $(\geq 10 \mathrm{~cm} \mathrm{GBH})$ density per transect ranges from 0 to 1220 individuals per ha with a mean of $374( \pm 8.88 \mathrm{SE})$. The highest density as well as species richness was recorded in tropical broadleaf semi-evergreen forests in the Lohit District (Transect: AR 208, Grid No: 92A5SW2 and Transect: AR 247, Grid No: 83M13SE3 respectively), whereas 16 transects were laid out in grids where the entire grid was covered by either a river or riverine grassland. The maximum diversity was recorded in the Lohit, Changlang and Tirap districts of Arunachal Pradesh. However, these forests were exposed to various levels of 


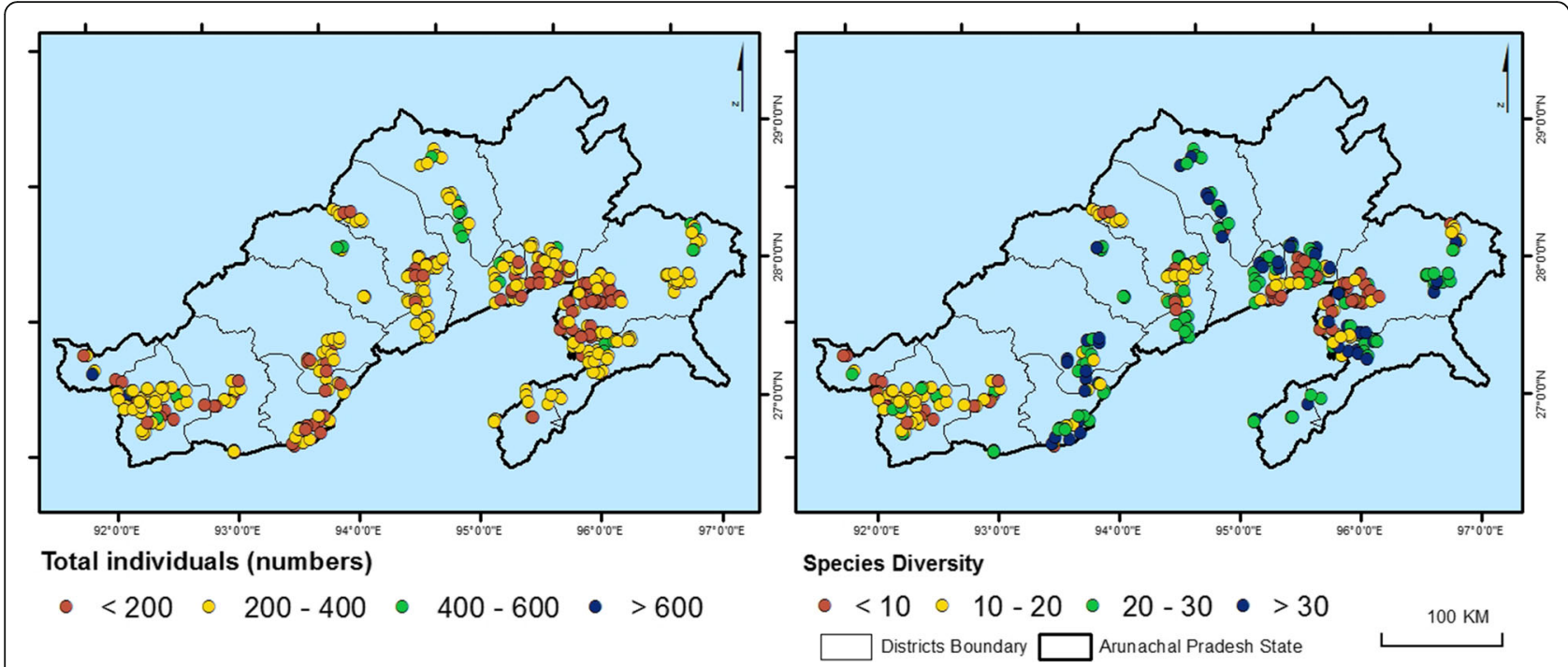

Fig. 2 Map showing the relationship between a total number of individuals and species diversity per transect in the eastern Himalayan forest

disturbances such as tree felling, fire, and encroachment (Fig. 3a-f).

A total number of 82,383 individuals of woody species were recorded in 354 studied transects with a stand density of 465 individuals per ha, whereas the density of herbaceous species was 375,777 individuals per ha, as recorded in 708 quadrants. The most dominant trees were Castanopsis indica (24 individuals per ha), followed by Quercus semicarpifolia (12 individuals per ha) and Pinus roxburghii (12 individuals per ha), preceded by various bamboos (Dendrocalamus strictus: 69 individuals per ha; Bambusa pallida: 16 individuals per ha; Table 3). In addition, Ageratum conyzoides (an invasive weed) was identified as the most dominant herb with 12,274 individuals per ha. The Eastern Himalayan forests are also rich in terms of invasive species and some dominant invasive include Lantana camara, Ageratum conyzoides, Chromolena odorata, and Eichhornia cressipes (dominant around higher altitude lakes).

In the present study, the Shannon-Wiener diversity value for trees and herbs was 4.64 and 4.12 , whereas the concentration of dominance was 0.02 and 0.03 , respectively. The different community parameters including quantitative

Table 2 Correlation between total number of individuals and species diversity in the studied transects

\begin{tabular}{llllll}
\hline $\begin{array}{l}\text { Number of individuals. } \\
\text { transect }^{-1}\end{array}$ & \multicolumn{6}{l}{ Species diversity class } \\
\cline { 2 - 6 } & $<10$ & $10-20$ & $20-30$ & $>30$ & Total \\
\hline$<200$ & 37 & 35 & 12 & 10 & 94 \\
$200-400$ & 18 & 61 & 83 & 74 & 236 \\
$400-600$ & 1 & 4 & 3 & 12 & 20 \\
$>600$ & 0 & 2 & 1 & 1 & 4 \\
Total & 56 & 102 & 99 & 97 & 354 \\
\hline
\end{tabular}

ecological characteristics of the studied forests are presented in Table 4. All 483 plant species (out of a total number of $484 \mathrm{spp}$.) were distributed contagiously in all the studied forest stands with an A/F ratio $>0.05$, whereas Phoebe cooperiana showed a regular distribution with an A/F ratio of 0.004 . Out of the total number of 329 woody plants, only 48 species were recorded in the seedling stage, competing with other herbs and grasses, which shows that only $14.59 \%$ of woody species were regenerating in 177 ha plots (354 studied transects).

The study exhibits distinct stratification (five different strata) on the basis of mean height of the species such as emergent $(>20 \mathrm{~m})$, canopy $(>10-20 \mathrm{~m})$, understorey $(>5-10 \mathrm{~m})$, shrub $(<5 \mathrm{~m}$ including sapling of the tree species) and ground $(<1 \mathrm{~m}$ including the saplings of both tree and shrub species). The highest percentage of species was found in the ground strata (31.66\%), followed by the understorey $(28.60 \%)$, and the lowest percentage was found in the emergent strata (1.31\%) (Fig. 4). In the emergent layer, there were only 6 species belonging to timber trees (Tetrameles nudiflora, Acacia pycnantha, Gymnocladus assamicus, Dysoxylum hamiltonii, Acer campbellii and Albizia lebbeck). Similarly, the canopy layer was occupied primarily by different timber trees and bamboos, whereas the understory was occupied primarily by Rhododendron spp., small timber and fruit trees.

The forest ecosystems in the Himalaya have been severely affected by natural disturbances including landslides, earthquakes, floods, cloudbursts, heavy rainfalls, as well as different biotic interferences. Landslides in the hilly areas and floods in the plain areas during rainy seasons are recurrent ecological disturbances experienced throughout the region. Besides this, the 

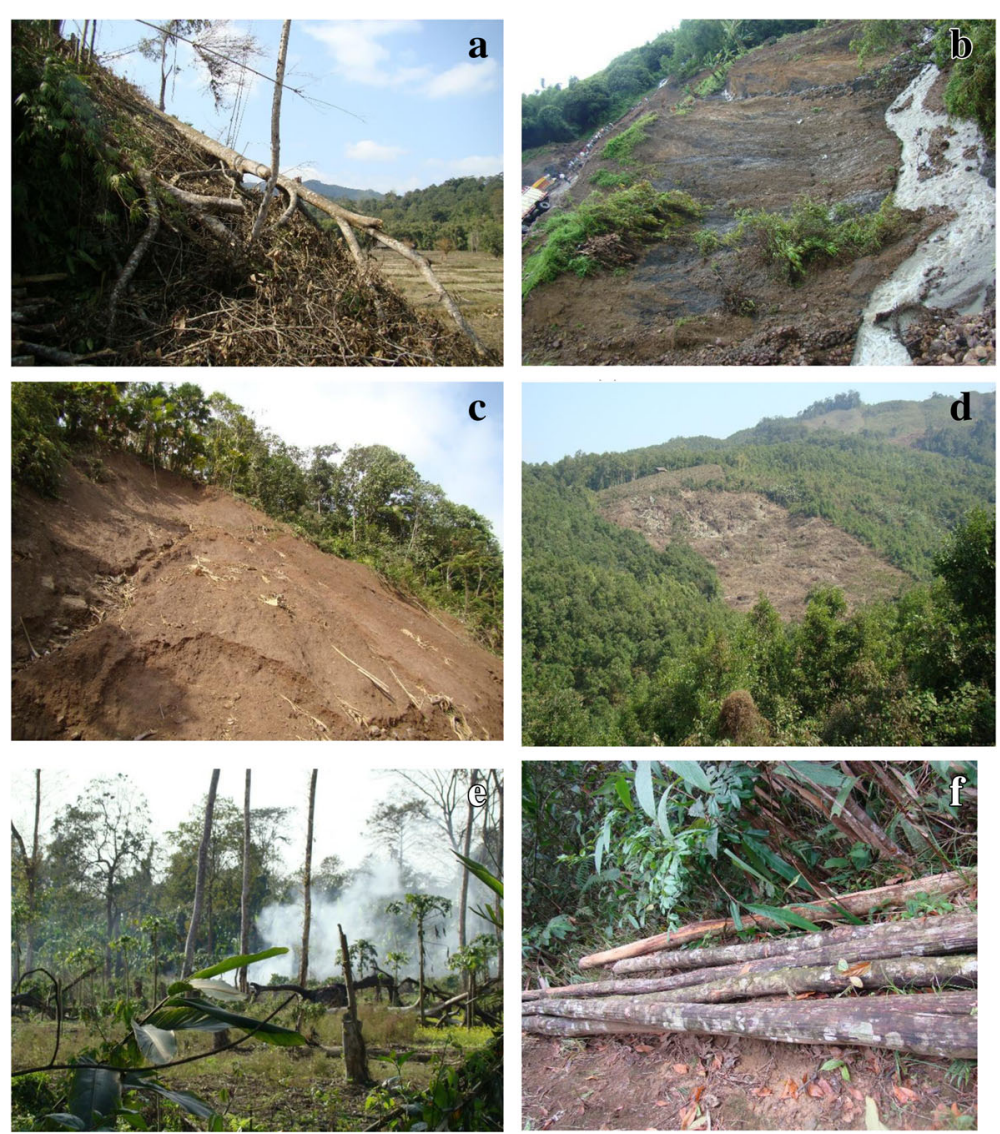

Fig. 3 Various disturbances (a) tree felling, (b) landslide due to heavy rainfall, (c) landslide, (d) forest clearance - Jhum, (e) forest fire, and (f) felled timber in natural forest of Arunachal Pradesh, Northeast India

Ranganadi Dam (a hydroelectric project managed by NEEPCO) is another major threat to its neighbouring forests located at the Lower Subansiri and Papumpare districts. Different types of biotic interferences such as fire, grazing, jhum, NTFPs collection, hunting, timber felling, etc. were encountered and observed during the field data collection, which are directly or indirectly influencing the composition of the forest. In some of the sampled grids, fire and grazing were recurrent phenomena. NTFPs collection by the local people was recorded in all the sampled grids. Firewood, resins, wild vegetables, fruits, toko leaves, fodder, medicinal plants etc. were the major NTFPs.

The resources of the forest are the main livelihood source for the people living in the Himalayan region, including Arunachal Pradesh. It must be noted that a

Table 3 List of 10 most important tree species and their density, frequency, dominance and IVI

\begin{tabular}{lllllllll}
\hline Name & Family & Density & RD & Frequency & RF & Dominance & RDm & IVI \\
\hline Dendrocalamus strictus & Poaceae & 68.95 & 14.81 & 47.18 & 3.64 & 55.68 & 1.72 & 20.18 \\
Duabanga grandiflora & Lythraceae & 9.26 & 1.99 & 21.75 & 1.68 & 296.14 & 9.15 & 12.82 \\
Bombax ceiba & Malvaceae & 6.58 & 1.41 & 22.32 & 1.72 & 285.51 & 8.82 & 11.95 \\
Castanopsis indica & Fagaceae & 23.81 & 5.12 & 24.86 & 1.92 & 153.35 & 4.74 & 11.77 \\
Terminalia myriocarpa & Combretaceae & 10.40 & 2.23 & 30.79 & 2.38 & 224.53 & 6.94 & 11.55 \\
Abies alba & Pinaceae & 6.33 & 1.36 & 3.67 & 0.28 & 178.06 & 5.50 & 7.14 \\
Gmelina arborea & Verbenaceae & 5.21 & 1.12 & 16.10 & 1.24 & 136.75 & 4.22 & 6.59 \\
Unknown & Unknown & 9.76 & 2.10 & 33.62 & 2.59 & 35.83 & 1.11 & 5.80 \\
Pinus roxburghii & Pinaceae & 11.64 & 2.50 & 8.19 & 0.63 & 85.64 & 2.65 & 5.78 \\
Quercus semicarpifolia & Fagaceae & 12.19 & 2.62 & 15.25 & 1.18 & 48.76 & 1.51 & 5.30 \\
\hline
\end{tabular}


Table 4 Community characteristics of Eastern Himalayan forests of Arunachal Pradesh, NE India

\begin{tabular}{|c|c|c|}
\hline Parameter & Woody plants & $\begin{array}{l}\text { Non-woody } \\
\text { plants }\end{array}$ \\
\hline Total number of plots studied (No.) & 354 transects & 708 quadrats \\
\hline Size of sampled area $\left(\mathrm{m}^{2}\right)$ & 5000 & 1 \\
\hline Actual sampled area (ha) & 177 & 0.0708 \\
\hline Dominant species & $\begin{array}{l}\text { Dendrocalamus } \\
\text { strictus }\end{array}$ & $\begin{array}{l}\text { Ageratum } \\
\text { conyzoides }\end{array}$ \\
\hline Dominant family & Ericaceae & Asteraceae \\
\hline No. of families (identified species) & 74 & 55 \\
\hline Species richness & 329 & 153 \\
\hline Density (individual.ha ${ }^{-1}$ ) & 465 & 375,777 \\
\hline Basal area of trees $\left(\mathrm{m}^{2} \cdot h \mathrm{a}^{-1}\right)$ & 3237.58 & - \\
\hline Diversity (Shannon's H') & 4.64 & 4.12 \\
\hline $\begin{array}{l}\text { Concentration of dominance } \\
\text { (Simpson index) }\end{array}$ & 0.02 & 0.03 \\
\hline Evenness Index & 0.81 & 0.78 \\
\hline $\begin{array}{l}\text { Species richness Index (Margalef } \\
\text { index of richness) }\end{array}$ & 28.01 & 15.81 \\
\hline
\end{tabular}

wide variety of medicinal plants used to be collected by the local people, to cure various diseases ranging from stomach ailments to blood pressure problems, as recorded during an informal discussion with the local villagers. Some of the most important medicinal plants recorded were Houttynia cordata, Drymaria cordata, Commelina benghalensis, Centella asiatica, Ageratum conyzoides, Scoparia dulcis, Spilanthesp aniculata, etc. All plant species ranging from medicinal herbs to timber trees are closely linked with the economic life of the local people. Details of some important plant species commonly used by the local villagers in the day to day necessities and subsistence generation are mentioned in Table 5.

The Eastern Himalayan forest in Arunachal Pradesh, Northeast India, is also rich in terms of various bamboos. In the present study, a total of 14 different bamboo species were recorded, including Dendrocalamus strictus, Bambusa tulda, B. pallida etc. The area is also rich in terms of various IUCN red-listed species, including Aquilaria malaccensis, Begonia tessaricarpa, Gledetsia assamica, Gymnocladus assamicus, Livistona jenkinsiana, Rhododendron meddenii, Rhododendron thomsonii, and Piper wallichii, which were collected primarily from the Dirrang, Tawang, Yamcha, Itanagar, Along and Mebo areas in Arunachal Pradesh. Some threatened species of Arunachal Pradesh are presented in Fig. 5a-f).

Out of the total number of 354 studied transects, 15 transects were laid out in alpine vegetation $(>2800 \mathrm{~m}$ altitude), 35 transects in temperate forests (m altitude), 70 transects in sub-tropical forests (m altitude), and 234 transects in tropical forests (m altitude) including 2 transects in a non-vegetation zone (covered by the river Siang). The species richness study exhibits the low variation in the alpine vegetation (the richness ranges from 2 to 21; mean $9 \pm 1.57 \mathrm{SE}$ ), the moderate variation in the temperate forests ( 5 to 44 ; mean $16 \pm 1.21 \mathrm{SE}$ ), the high variation in the sub-tropical forests (5 to 53; mean $24 \pm 1.27 \mathrm{SE}$ ), and the very high variation in the tropical forests ( 0 to 64 ; mean $23 \pm 0.84 \mathrm{SE}$ ) (Table 6). The 15 studied transects in the alpine forests (7.5 ha area) are located in the West Kameng and Tawang districts with a loamy soil covered by mixed semi-evergreen forests, where tree density ranges from 196 to 600 individuals per ha (mean $407 \pm 28.40 \mathrm{SE}$ ). There is occasional biotic interference in the studied forests, mainly due to collection of fuelwood and grazing. Occasional NTFPs collection, looping, soil removal as well as forest fire were also evident in some forest patches, though tree felling was not observed in any of the studied forests. Similarly, the 35 studied temperate forests (17.5 ha area) were located at the West Kameng, West Siang and Lower Subansiri districts, with loamy to clayey soil with humus, covered mainly by mixed to coniferous semi-evergreen forests as well as grasslands, where the tree density ranges from 0 to 1220 individuals per ha (mean $413 \pm 41.75 \mathrm{SE}$ ). The two transects of Mechukha in West Siang were laid out in grasslands used primarily by locals for grazing and with no tree covers. Looping,

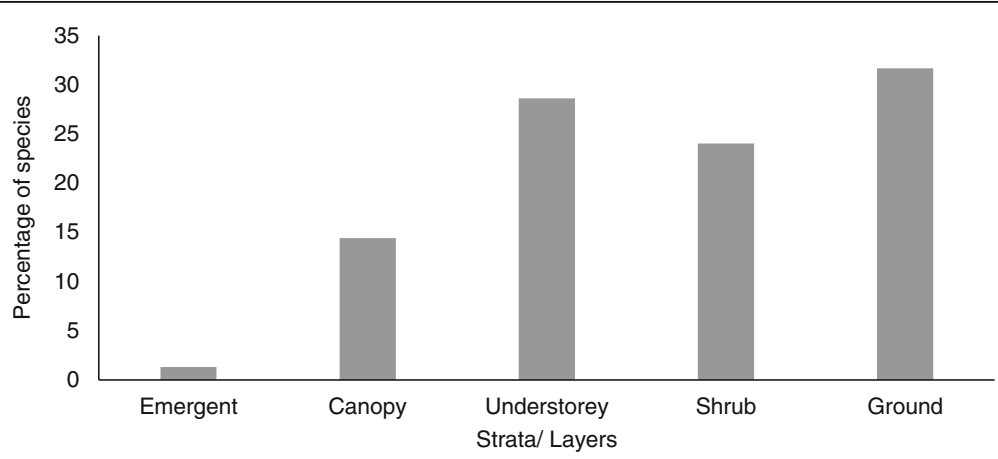

Fig. 4 Distribution of species in different strata of studied forests according to their mean height 
Table 5 Some of the economically as well as locally used important plants species recorded from the sampled grids

\begin{tabular}{ll}
\hline Timber & Dipterocarpus macrocarpus, Terminalia myriocarpa, Lagerstroemia speciosa, Morus laevigata, Gmelina arborea, \\
& Pterospermum acerifolium, Toona ciliata, Altingia excelsa, Duabanga grandiflora, Shorea assamica, Shorea robusta, \\
& Schima wallichii, Mesua ferrea, Stereospermum chelonoides, Kyida glabreseeus, Tectona grandis, Pinus roxburghii, \\
& Castonopsis indica, Bombax ceiba, Dulbergia sissoo, Michelia champaca, Anthocephalus chinensis \\
\hline Medicinal & Oroxylum indicum, Terminalia balerica, Terminalia chebula, Phyllathus emblica, Xanthium strumarium, \\
& Commelina benghalensis, Cynodon dactylon, Centella asiatica, Chelerodendrum viscosum, Leucus aspera, \\
& Rhododendron arboreum, Garcinia cowa, Azadirachta indica, Callicarpa arborea, Caryota urens, Cyathea spinulosa, \\
& Dillenia indica, Spilanthes paniculata, Piper wallichii, Piper sylvaticum, Piper mullsua, Valeriana wallichii, Cassia fistula \\
Fuel wood and fodder & Albizia lebbeck, Alnus nepalensis, Rhododendron arboreum, Cassia fistula, Alstonia scholaris, Castonopsis indica, \\
& Pinus roxburghii, Pinus wallichiana, Quercus semicarpifolia, Mallotus phillipensis, Macaranga denticulata, \\
Lantana camara, Zizyphus mauritiana, Bambusa spp. \\
Dye yielding \\
Thatch
\end{tabular}

grazing and fuelwood collection are the common biotic interferences in this region. The 70 studied transects in the sub-tropical forests (35 ha area) were located in 12 different districts of Arunachal Pradesh, where tree density ranges from 192 to 902 individuals per ha (mean $419 \pm 15.29 \mathrm{SE}$ ), with diverse vegetation types including mixed semi-evergreen, mixed evergreen, mixed deciduous, broadleaf semi-evergreen, coniferous evergreen and coniferous semi-evergreen. On the other hand, most of the transects (234 transects covering 116 ha area) were laid out in tropical forests covering nine different districts of Arunachal Pradesh, where the tree density ranges from 0 to 650 individuals per ha (mean $352 \pm 10.63 \mathrm{SE}$ ) and the vegetation is mainly broadleaf semi-evergreen, mixed
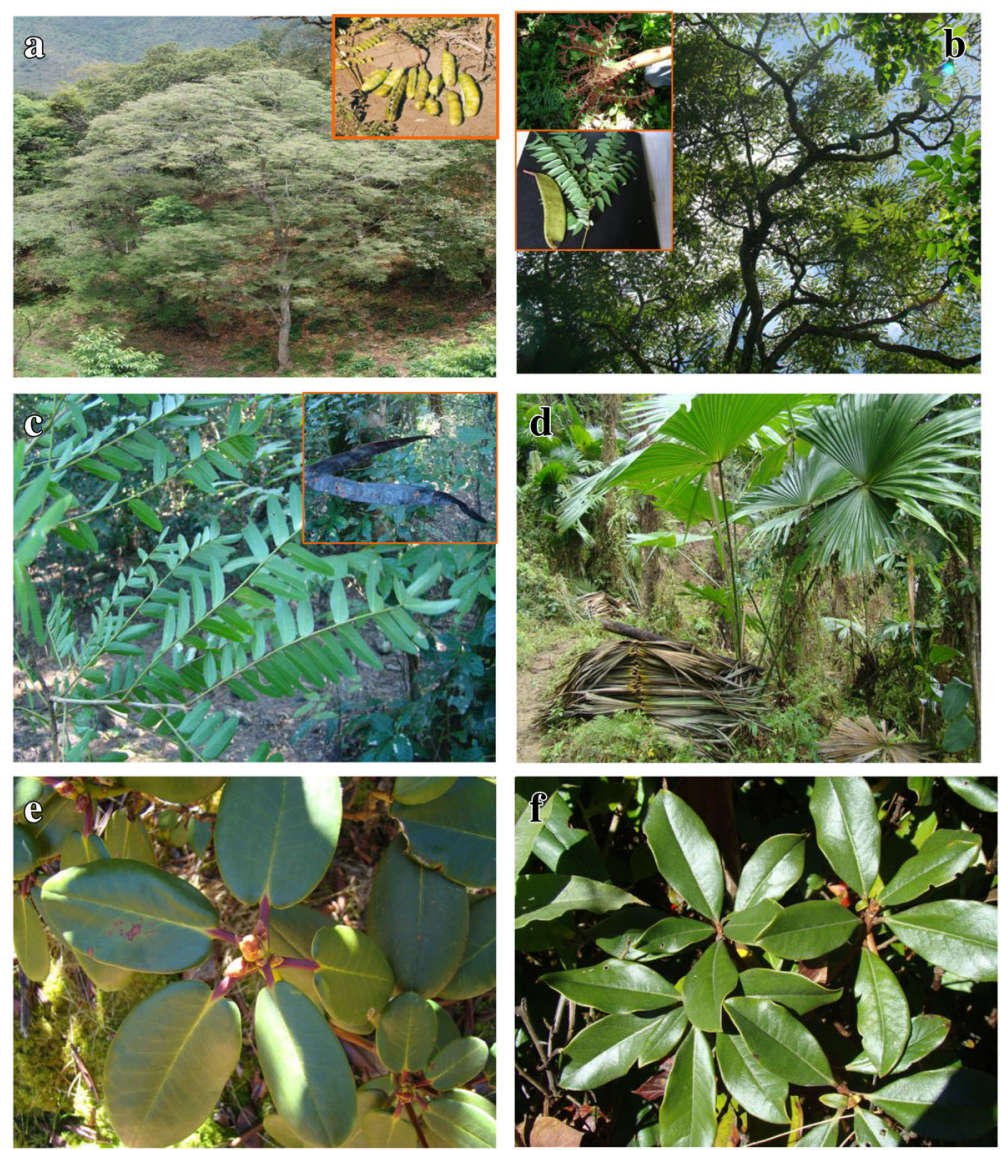

Fig. 5 Some threatened species of Arunachal Pradesh (a and $\mathbf{b})$ tree, pods and seedling of Gymnocladus assamicus and Gymnocladu schinensis; (c) Leaves and Pods of Gledetsia assamica; (d) Tree and harvested leaves of Livistona jenkinsiana; (e) Rhododendron fulgens; (f) Rhododendron meddenii 
Table 6 Species richness and stand density of studied forests at different altitudinal gradients of Arunachal Pradesh, Northeast India

\begin{tabular}{|c|c|c|c|c|c|}
\hline $\begin{array}{l}\text { Climatic } \\
\text { zone }\end{array}$ & $\begin{array}{l}\text { No. of transects } \\
\text { studied }\end{array}$ & $\begin{array}{l}\text { Altitude } \\
\text { range (m) }\end{array}$ & Located districts & Species richness (No.) & $\begin{array}{l}\text { Stem density } \\
(\geq 10 \mathrm{~cm} \mathrm{GBH}) \\
\text { (individuals } \cdot h a^{-1} \text { ) }\end{array}$ \\
\hline Alpine & 15 & $2803-4161$ & Tawang and West Kameng & $\begin{array}{l}2 \text { to } 21 \\
\text { (mean } 9 \pm 1.57 \mathrm{SE} \text { ) }\end{array}$ & $\begin{array}{l}196-600 \\
(\text { mean } 407 \pm 28.40 \mathrm{SE})\end{array}$ \\
\hline Temperate & 35 & $1824-2788$ & West Kameng, West Siang and Lower Subansiri & $\begin{array}{l}5 \text { to } 44 \\
\text { (mean } 16 \pm 1.21 \mathrm{SE} \text { ) }\end{array}$ & $\begin{array}{l}0-1220 \\
\text { (mean } 413 \pm 41.75 \mathrm{SE})\end{array}$ \\
\hline Sub-Tropical & 70 & $802-1800$ & $\begin{array}{l}\text { West Kameng, East Kameng, West Siang, East Siang, } \\
\text { Upper Siang, Lower Subansiri, Upper Subansiri, } \\
\text { Lower Dibang Valley, Anjaw, Papumpare, } \\
\text { Tirap and Changlang }\end{array}$ & $\begin{array}{l}5 \text { to } 53 \\
\text { (mean } 24 \pm 1.27 \mathrm{SE} \text { ) }\end{array}$ & $\begin{array}{l}\text { 192-902 } \\
\text { (mean } 419 \pm 15.29 \mathrm{SE})\end{array}$ \\
\hline Tropical & 234 & $87-795$ & $\begin{array}{l}\text { East Kameng, West Siang, East Siang, Upper Siang, } \\
\text { Upper Subansiri, Lower Dibang Valley, Lohit, Papumpare, } \\
\text { Tirap and Changlang }\end{array}$ & $\begin{array}{l}0 \text { to } 64 \\
\text { (mean } 23 \pm 0.84 \mathrm{SE} \text { ) }\end{array}$ & $\begin{array}{l}0-650 \\
\text { (mean } 352 \pm 10.63 \mathrm{SE} \text { ) }\end{array}$ \\
\hline
\end{tabular}

semi-evergreen, broadleaf deciduous, broadleaf evergreen, and evergreen bamboo to grassland. In some grids, the tree density was zero, as 12 transects were laid out in grassland having no tree cover. Most of the tropical and sub-tropical forests were experiencing different degrees of anthropogenic pressure, including looping, fuelwood collection, fire, NTFPs collection, soil removal, grazing, litter collection, tree felling etc., which are influencing the forest diversity of the region.

\section{Discussions}

Understanding species diversity and distribution patterns is significant for helping managers to evaluate the complexity as well as the prospects of forest ecosystems. The level of species richness in the studied forests can be attributed to microclimatic variations at different altitudinal gradients. Studying the microclimate is important because of its significant effects on species richness and ecosystem functions. Apart from microclimatic factors, plant species may respond to fine-scale variation in $\mathrm{pH}$ (Jansen and Oksanen 2013), and soil moisture and nutrients (Fischer et al. 2014). A higher diversity of woody plants was observed in the present study, as compared to herbaceous species; however, reverse data (herbaceous plants > trees and shrubs) was presented from Northwest Himalayan forests of India (Sharma et al. 2014). The greater richness of woody plants, particularly observed in the trees, could also be the result of the succession process that tends to increase species diversity in the studied forests. The present study recorded Fabaceae as the most species-rich family with $27 \mathrm{spp}$. and 49 monotypic families, whereas Asteraceae was the dominant family with $49 \mathrm{spp}$. and 28 monotypic families in the Western Himalayan forests of India (Sharma et al. 2014). This difference may be due to the variations in terms of growth forms, as trees and shrubs are dominant in the Eastern Himalayan forests, whereas herbs are dominant in the Western Himalayan forests.
Despite the high level of disturbance due to tree felling, fire, and encroachment, the higher diversity in the Lohit, Changlang and Tirap districts may be due to the higher rainfall as compared to other parts of the state, which promotes soil nutrient and $\mathrm{pH}$ to facilitate organic matter decomposition. In general, tree density varies with forest community type, forest age class, tree species and size class, site history, site condition, and other factors. The recorded tree density (465 individuals per ha) in the present study is comparable with the reported value from other tropical forests (Saxena and Singh 1982; Singh et al. 1984; Parthasarathy et al. 1992; Swan Jr, 1988; Sharma et al. 2014), but it is lower than the recorded density of Northeast Indian forests (Bhuyan et al. 2003; Duchok et al. 2005; Kumar et al. 2006). However, the reported $3237.58 \mathrm{~m}^{2} \cdot \mathrm{ha}^{-1}$ basal cover of 82,383 individuals of woody species was found to be significantly higher than the recorded basal cover of tropical forests (Bhuyan et al. 2003; Kumar et al. 2006). Differences in the basal area may be attributed to altitudinal variations, species composition, age structure and successional stage of the forest (Swamy et al. 2000). The Shannon-Wiener diversity index is generally high for tropical forests of the Indian subcontinent and ranges from 0.81 to 4.1 (Singh et al. 1984; Parthasarathy et al. 1992; Bhuyan et al. 2003). The recorded Shannon-Wiener diversity values for trees and herbs in the present study were 4.64 and 4.12 , which was slightly higher than the previously recorded values. In general, species diversity and concentration dominance show an inverse relationship (Singh and Mishra 1969; Joshi and Behera 1991). The values of species diversity corresponded to the general trend i.e., tree > herb, while the concentration dominance displayed the opposite trend i.e., herb $>$ tree in the investigated forests. The high diversity and low concentration dominance in the analyzed forests may be due to different levels of anthropogenic pressure in different forests at varied locations. Dispersal limitation is an important ecological factor for controlling species' distribution pattern (Hubbell et al. 1999). Contagious 
distribution has been accepted as a characteristic pattern of plant occurrence in nature (Odum 1971); it is an indication of clusteredness. Only $14.59 \%$ of woody species were recorded in a seedling stage, which signifies a very poor rate of regeneration of woody species in the 177 ha studied plots (354 transects). This may be due to the uneven timing of sampling (different months during June 2007 to April 2010). On the other hand, seedling recruitment was poorer in the higher altitude forests due to the thick ground cover of leaf litter (mainly in coniferous forests).

Multilayered canopy configuration is characterized by the presence of a large number of heterogeneous microsites, which signifies the suitability and ecological efficiency of the system in terms of sharing, utilization and conservation of the available resources like sunlight, water and soil (Wiersum 1982; Torquebiau 1992). A heterogeneous canopy structure is a relevant attribute of tropical forests in physiognomic terms. In addition, the degree of vertical stratification is an important factor for maintaining higher woody species diversity in natural forests (Feroz et al. 2006, 2008). In conformity with the present study, the tropical wet evergreen forests of Bangladesh also showed five distinct strata, with the highest species diversity in the ground strata (Feroz et al. 2016). Generally, the lower strata support the high species richness in a forest (Feroz et al. 2006). On the other hand, Feroz et al. (2015) recorded four distinct strata in the subtropical evergreen broadleaf forests of Japan.

Elevation gradients are ideally suited for examining biodiversity drivers, as elevation is correlated with various environmental variables including competition, mutualism, ecotone effects, temperature and rainfall, which determine energy availability and ecosystem productivity (McCain and Grytnes 2010). Two main patterns of species richnesselevation relationships are dominant in the relevant literature, i.e. decreasing and hump-shaped (Rahbek 1995). Incomplete sampling of environmental gradients can directly bias the resulting pattern. The present study confirms that species richness decreases with increase in altitude, in conformity with earlier studies (Bachman et al. 2004; Jacquemyn et al. 2005; Trigas et al. 2013). With the increase in altitude, species diversity decreases as a result of environmental filtering, and because the higher altitude ecosystems have been mainly colonized by plant species tolerant of extreme weather conditions. Differences in species diversity among communities generally resulted from variations in site specificity (Denslow 1980). Moreover, species diversity is often correlated with the rainfall and nutrient status of the site (Hartshorn 1980). On the other hand, the density of trees increases with altitude from the tropical to the temperate range, and then it decreases in the alpine zone as the vegetation is usually sparse above an altitude of $3000 \mathrm{~m}$ (Singh et al. 1994). The highest density of trees was recorded in the forests of temperate zones as temperate zones are dominated mainly by coniferous species with straight stem/bole and can accommodate more plants. Tree density varied greatly in the middle altitude (1824-2788 m altitude) forest ranges from 0 to 1220 individuals per ha (mean $413 \pm 41.75 \mathrm{SE}$ ) as two transects of Mechukha, West Siang were laid out in grasslands used by locals as grazing land and having no tree cover. Similar findings have also been reported by Singh et al. (1994) for the Central Himalayan forests.

\section{Conclusion}

The study exhibits that the Eastern Himalayan forests are very rich in terms of floristic composition (482 plant species). The species richness decreases with the increasing elevation. Species richness and distribution patterns of plants are largely regulated by the altitude and environmental factors. Knowledge of the relative contribution of spatial and environmental variation on the species' compositional patterns along large-scale gradients would help forest managers to understand the processes that primarily maintain plant species patterns. The study also confirms that the Eastern Himalayan forests are extremely rich in endemic as well as non-endemic species. This needs regular intensive monitoring and management to conserve the fragile ecosystems from the ever-increasing anthropogenic pressure in changing climatic conditions.

\section{Abbreviations \\ GBH: Girth at Breast Height; IUCN: The International Union for Conservation of Nature; NEEPCO: North Eastern Electric Power Corporation Limited; NTFPs: Non-Timber Forest Products; spp.: Species}

\section{Acknowledgements}

Financial support from DBT, Govt. of India, through the project 'Mapping and quantitative assessment of geographic distribution and population status of plant resources of Eastern Himalayan region' is highly acknowledged (Reference no. BT/PR7928/NDB/52/9/2006 dated 29.09.2006). The authors acknowledge the support and assistance of Ziaur Rahman Laskar, Salam Dilip, Bijit, Bironjoy and Samar during field visits of the study.

\section{Availability of data and materials}

The data is shared with Global Forestry Biodiversity Initiative (GFBI) and available upon request to the Corresponding Author.

\section{Authors' contributions \\ JD and SB participated in the data collection, analysis and interpretation, species identification and herbarium processing; AK prepared the maps and also helped in the manuscript preparation and statistical analysis; PS entered, analysed and formatted data and also drafted the manuscript. OPT and LBS participated in field design, coordinated during data collection; SD helped in data presentation and also finalized the manuscript, and MLK conceived the study, coordinated among other teams (as it is part of a mega project conducted in eight Northeastern states) and forest officials of different parts of Arunachal Pradesh and also contributed in finalizing the manuscript. All authors read and approved the final manuscript.}

\section{Funding}

This study is an output of a project funded by the Department of Biotechnology (DBT), Government of India, New Delhi (Reference no. BT/ PR7928/NDB/52/9/2006 dated 29.09.2006). 


\section{Authors' information}

P. Saikia is Assistant Professor in the Centre for Environmental Sciences, School of Natural Resource Management, Central University of Jharkhand, Ranchi, Jharkhand, India. J. Deka is Assistant Professor in the Department of Botany, University of Science and Technology, Meghalaya (USTM), Meghalaya, India. S. Bharali is working in the Rubber Board of India, Regional Office, Dimapur-797,112, Nagaland, India. A. Kumar is Assistant Professor in the Centre for Land Resource Management, School of Natural Resource Management, Central University of Jharkhand, Ranchi, Jharkhand, India. O.P. Tripathi and L.B. Singha are Associate Professors in the Department of Forestry, North Eastern Regional Institute of Science \& Technology, Nirjuli, Arunachal Pradesh, India. S. Dayanandan is Professor in the Centre for Structural and Functional Genomics, Biology Department, Concordia University, Montreal, Canada. M.L. Khan is Professor in the Department of Botany, Dr. Harisingh Gour Central University, Madhya Pradesh, India.

\section{Ethics approval and consent to participate}

Not applicable.

\section{Consent for publication}

Not applicable.

\section{Competing interests}

The authors declare that they have no competing interests.

\section{Author details}

'School of Natural Resource Management, Central University of Jharkhand, Brambe, Ranchi, Jharkhand 835205, India. ${ }^{2}$ Department of Botany, University of Science and Technology, Meghalaya (USTM), 9th Mile, G.S Road, Ribhoi, Baridua, Meghalaya 793101, India. ${ }^{3}$ Rubber Board of India, Regional Office, Dimapur, Nagaland 797112, India. ${ }^{4}$ Department of Forestry, North Eastern Regional Institute of Science \& Technology (Deemed University), Nirjuli, Itanagar, Arunachal Pradesh 791109, India. ${ }^{5}$ Centre for Structural and Functional Genomics, Biology Department, Concordia University, 7141 Sherbrooke St, Quebec, West, Montreal H4B 1R6, Canada. ${ }^{6}$ Department of Botany, Dr. Harisingh Gour Central University, Sagar, Madhya Pradesh 470003, India.

\section{Received: 16 August 2017 Accepted: 27 November 2017}

Published online: 21 December 2017

\section{References}

Armenteras D, Rodriguez N, Retana J (2009) Are conservation strategies effective in avoiding the deforestation of the Colombian Guyana shield? Biol Conserv 42:1411-1419

Bachman S, Baker WJ, Brummitt N, Dransfield J, Moat J (2004) Elevational gradients, area and tropical island diversity: an example from the palms of new Guinea. Ecography 27:299-310

Bhuyan P, Khan ML, Tripathi RS (2003) Tree diversity and population structure in undisturbed and human-impacted stands of tropical wet evergreen forest in Arunachal Pradesh, eastern Himalayas, India. Biodivers Conserv 12:1753-1773

Billings WD (1952) The environment complex in relation to plant growth and distribution. Q Rev Biol 27(3):251-265

Census of India (2011) Census report, Office of the Registrar General \& Census Commissioner. Ministry of Home Affairs, Government of India, India

Chapin FS, Autumn K, Pugnaire F (1993) Evolution of suites of traits in response to environmental stress. Am Nat 142:S78-S92

Chatterjee S (1995) Global hotspots of biodiversity. Curr Sci 68(12):1178-1179

Curtis JT, Cottam G (1956) Plant ecology work book. Laboratory field reference manual. Burgess Publishing Company, Minnesota

Denslow JS (1980) Gap partitioning among tropical rainforest trees. Biotropica (Suppl) 12:47-55

Duchok R, Kent K, Khumbongmayum AD, Paul A, Khan ML (2005) Population structure and regeneration status of medicinal tree Illicium griffithii in relation to disturbance gradients in the temperate broad-leaved forest of Arunachal Pradesh. Curr Sci 89:673-676

Feroz SM, Hagihara A, Yokota M (2006) Stand structure and woody species diversity in relation to the stand stratification in a subtropical evergreen broadleaf forest. Okinawa Island. J Plant Res 119:293-301
Feroz SM, Yoshimura K, Hagihara A (2008) Stand stratification and woody species diversity of a subtropical forest in limestone habitat in the northern part of Okinawa Island. J Plant Res 121:329-337

Feroz SM, Kabir ME, Hagihara A (2015) Species composition, diversity and stratification in the subtropical evergreen broadleaf forest along a latitudinal thermal gradient in the Ryukyu archipelago. Japan Glob Ecol Cons 4:63-72

Feroz SM, Mamun AA, Kabir ME (2016) Composition, diversity and distribution of woody species in relation to vertical stratification of a tropical wet evergreen forest in Bangladesh. Global Ecol Conserv 8:144-153

Fischer H, Micler B, Ewald J (2014) Environmental, spatial and structural components in the composition of mountain forest in the Bavarian alps. Folia Geobot 49:361-384

Hartshorn GS (1980) Neotropical forest dynamics. Biotropica (Supplement) 12: 23-30

Heady HF (1958) Vegetational changes in the California annual type. Ecology 39(3):402-416. https://doi.org/10.2307/1931750

Huang W, Pohjonen V, Johasson S, Nashanda M, Katigula MIL, Luukkanen O (2003) Species diversity, forest structure and species composition in Tanzanian tropical forests. For Ecol Manag 173:111-124

Hubbell SP, Foster RB, O'Brien S, Wechsler B, Condit R, Harms K, Wright SJ, Loo de Lau $S$ (1999) Light gaps, recruitment limitation and tree diversity in a Neotropical forest. Science 283:554-557

Hundera K, Bekele T, Kelbessa E (2007) Floristic and phytogeographic synopsis of a dry afromontane coniferous forest in Bale Mountains, Ethiopia: implication to biodiversity conservation. SINET: Ethiop J Sci 30:1-12

Jacquemyn H, Micheneau C, Roberts DL, Pailler T (2005) Elevational gradients of species diversity, breeding system and floral traits of orchid species on Réunion Island. J Biogeogr 32:1751-1761

Jansen F, Oksanen J (2013) How to model species responses along ecological gradients - Huisman-Olff-fresco models revisited. J Veg Sci 24:1108-1117

Joshi SK, Behera N (1991) Qualitative analysis of vegetation from mixed tropical forests of Orissa, India. Ind Forest 117:200-206

Kobayashi S (2004) Landscape rehabilitation of degraded tropical forest ecosystems. A case study of the CIFROR/Japan project in Indonesia and Peru. For Ecol Manag 201:13-22. https://doi.org/10.1016/j.foreco.2004.06.009

Kumar A, Bruce GM, Saxena A (2006) Tree species diversity and distribution patterns in tropical forests of Garo Hills. Curr Sci 91(10):1370-1381

Li YD, Zhou GY, Zeng QB, Wu ZM, Luo TS (2003) The values for ecological service function of tropical natural forest in Hainan Island, China (in Chinese). Forest Res 16:146-152

Magurran AE (1988) Why diversity. In: Ecological diversity and its measurement. Springer, Netherlands, pp 1-5

McCain CM, Grytnes JA (2010) Elevational gradients in species richness. Encyclopedia of life sciences (ELS). John Wiley \& Sons, Ltd, Chichester, pp 1-10

Mishra D, Mishra TK, Banerjee SK (1997) Comparative phytosociological and soil physico-chemical aspects between managed and unmanaged lateritic land. Ann Forest 5(1):16-25

Misra R (1968) Ecology workbook. Oxford \& IBH Publishing Company, Calcutta, India

Myers N, Mittermeier RA, Mittermeier CG, da Fonseca GAB, Kent J (2000) Biodiversity hotspots for conservation priorities. Nature 403:853-858

Odum HT (1971) Fundamentals of ecology. W.B. Saunders and Co, Phiadelphia, p 574

Parthasarathy N, Kinhal V, Kumar LP (1992) Plant species diversity and human impacts in the tropical wet evergreen forests of southern western Ghats. Indo-French workshop on tropical Forest ecosystems: natural functioning and anthropogenic impact. French Institute, Pondicherry

Pimm SL, Raven P (2000) Extinction by numbers. Nature 403:843-845

Rahbek C (1995) The elevational gradient of species richness: a uniform pattern? Ecography 18:200-205

Ramachandra TV, Joshi NV, Kumar U, Krishnadas G, Rao GR, Bharath HA, Bharath S, Rajasri R, Shwetmala DG, Gururaja KV, Yadav AS (2013) Aboveground biomass and biomass productivity of three micro watersheds across altitudinal gradients in western Himalaya. CES technical report 131. Ecological Modelling and Energy DSS, Bangalore, India, pp 1-12

Saxena AK, Singh JS (1982) A phytosociological analysis of woody species in forest communities of a part of Kumaun Himalaya. Vegetation 50(1):3-22

Shannon CE, Wiener W (1963) The mathematical theory of communication. University of Illinois Press, Urbana

Sharma P, Rana JC, Devi U, Randhawa SS, Kumar R (2014) Floristic diversity and distribution pattern of plant communities along altitudinal gradient in Sangla Valley, northwest Himalaya. Sci World J 2014:1-11. https//doi.org/10.1155/2014/264878

Simpson EH (1949) Measurement of diversity. Nature 163:688

Singh JS, Mishra R (1969) Diversity, dominance, stability, net primary production in the grassland at Varanasi. Can J Bot 47:425-427 
Singh L, Singh JS (1991) Species structure, dry matter dynamics and carbon flux of a dry tropical forest in India. Ann Bot 68:263-273

Singh JS, Singh SP, Saxena AK, Ravat YS (1984) The forest vegetation of Silent Valley. Tropical rain forests - the Leeds symposium, pp 25-52

Singh SP, Adhikari BS, Zobel DB (1994) Biomass, productivity, leaf longevity, and forest structure in the central Himalaya. Ecol Monogr 64:401-421

Swamy PS, Sundarapandian SM, Chandrasekar P, Chandrasekaran S (2000) Plant species diversity and tree population structure of a humid tropical forest in Tamil Nadu, India. Biodivers Conserv 9:1643-1669. https://doi.org/10.1023/A: 1026511812878

Swan FR Jr (1988) Tree distribution patterns in the Bukittimah nature reserve, Singapore. Gar Bull (Singapore) 41:59-81

Torquebiau E (1992) Are tropical agroforestry home gardens sustainable? Agr Ecosyst Environm 41:189-207

Trigas P. Panitsa M, Tsiftsis S (2013) Elevational gradient of vascular plant species richness and endemism in Crete - the effect of post-isolation mountain uplift on a continental island system. PLoS One 8(3):e59425. https://doi.org/ 10.1371/journal.pone.0059425

Whitford PB (1949) Distribution of woodland plants in relation to succession and clonal growth. Ecology 30:199-288

Whitmore TC (1998) An introduction to tropical rain forests. Oxford University Press, New York

Wiersum KF (1982) Tree gardening and Taungya on java: examples of agroforestry techniques in the humid tropics. Agrofor Syst 1:53-70

\section{Submit your manuscript to a SpringerOpen ${ }^{\circ}$ journal and benefit from:}

- Convenient online submission

- Rigorous peer review

- Open access: articles freely available online

- High visibility within the field

- Retaining the copyright to your article

Submit your next manuscript at $\gg$ springeropen.com 